\title{
Phosphor converted laser diode light source for endoscopic diagnostics
}

Krasnoshchoka, Anastasiia; Thorseth, Anders; Dam-Hansen, Carsten; Corell, Dennis Dan; Petersen, Paul Michael; Jensen, Ole Bjarlin

Publication date:

2017

Document Version

Publisher's PDF, also known as Version of record

Link back to DTU Orbit

Citation (APA):

Krasnoshchoka, A., Thorseth, A., Dam-Hansen, C., Corell, D. D., Petersen, P. M., \& Jensen, O. B. (2017). Phosphor converted laser diode light source for endoscopic diagnostics. Poster session presented at CIE Midterm Meeting 2017 , Jeju, Korea, Republic of.

\section{General rights}

Copyright and moral rights for the publications made accessible in the public portal are retained by the authors and/or other copyright owners and it is a condition of accessing publications that users recognise and abide by the legal requirements associated with these rights.

- Users may download and print one copy of any publication from the public portal for the purpose of private study or research.

- You may not further distribute the material or use it for any profit-making activity or commercial gain

- You may freely distribute the URL identifying the publication in the public portal

If you believe that this document breaches copyright please contact us providing details, and we will remove access to the work immediately and investigate your claim 


\title{
PHOSPHOR CONVERTED LASER DIODE LIGHT SOURCE FOR ENDOSCOPIC DIAGNOSTICS
}

\author{
Krasnoshchoka A., Thorseth, A., Dam-Hansen, C., Corell, D.D., Petersen, P.M., Jensen, O.B.
}

Highly efficient endoscopic white light sources may be enabled by use of phosphor converted blue laser diodes. This light source offers the advantages of a more compact and ergonomic design, lower cost, possibility of tailoring the spectral content and more uniform illumination in comparison with current technology, as well as providing the possibility of shadow formation within the operative field.

Phosphor converted laser diode light source for endoscopy set-up

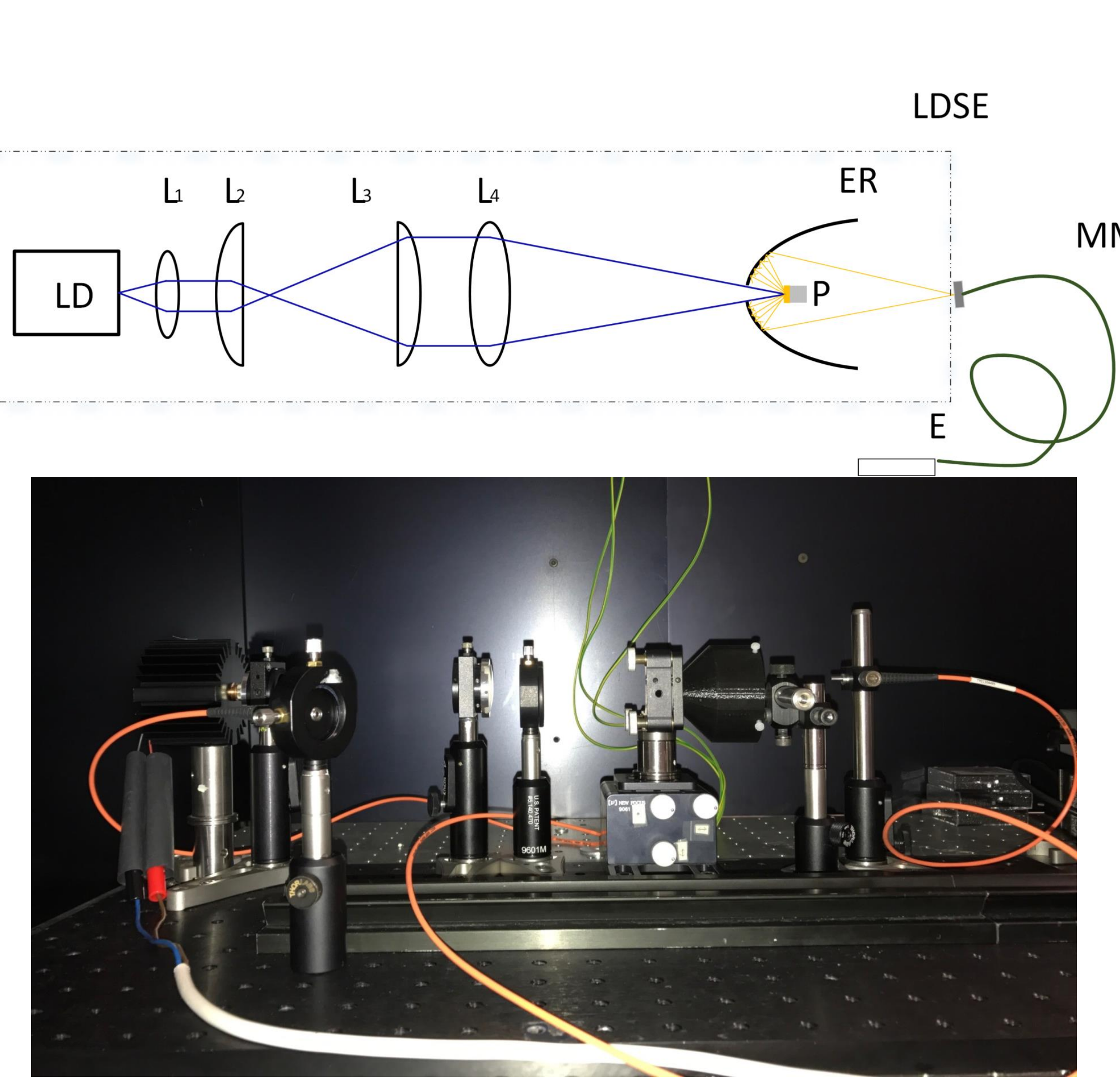

We present a novel endoscopic illumination source, based on the use of a blue LD and a mixture of the down-converting materials Ce:LuAG and Eu-doped nitride yellow phosphor for the production of white light. We have been investigating general behavior of the ceramic phosphors and their tendency to saturate under certain intensity of illumination.

Among the main advantages are higher efficiency, much better coupling efficiency into thin fibers and possibility of tailoring the spectral content. It is also worth mentioning that in our prototype, the phosphor material is not situated at the distal end of the endoscope and light is being converted before coupling into a fiber, thus it is not toxic for the patient.

With our PC-LD light source we achieved comparable illuminance as a commercially available D-Light $C$ xenon lamp. We were also able to couple generated white light from PC-LD into thin optical fibers $(400 \mu \mathrm{m}, 600 \mu \mathrm{m}, 1000 \mu \mathrm{m})$ with a maximal coupling efficiency of $55 \%$.

\section{Spectral characteristics endoscopic light sources at $4 \mathrm{~cm}$ distance}

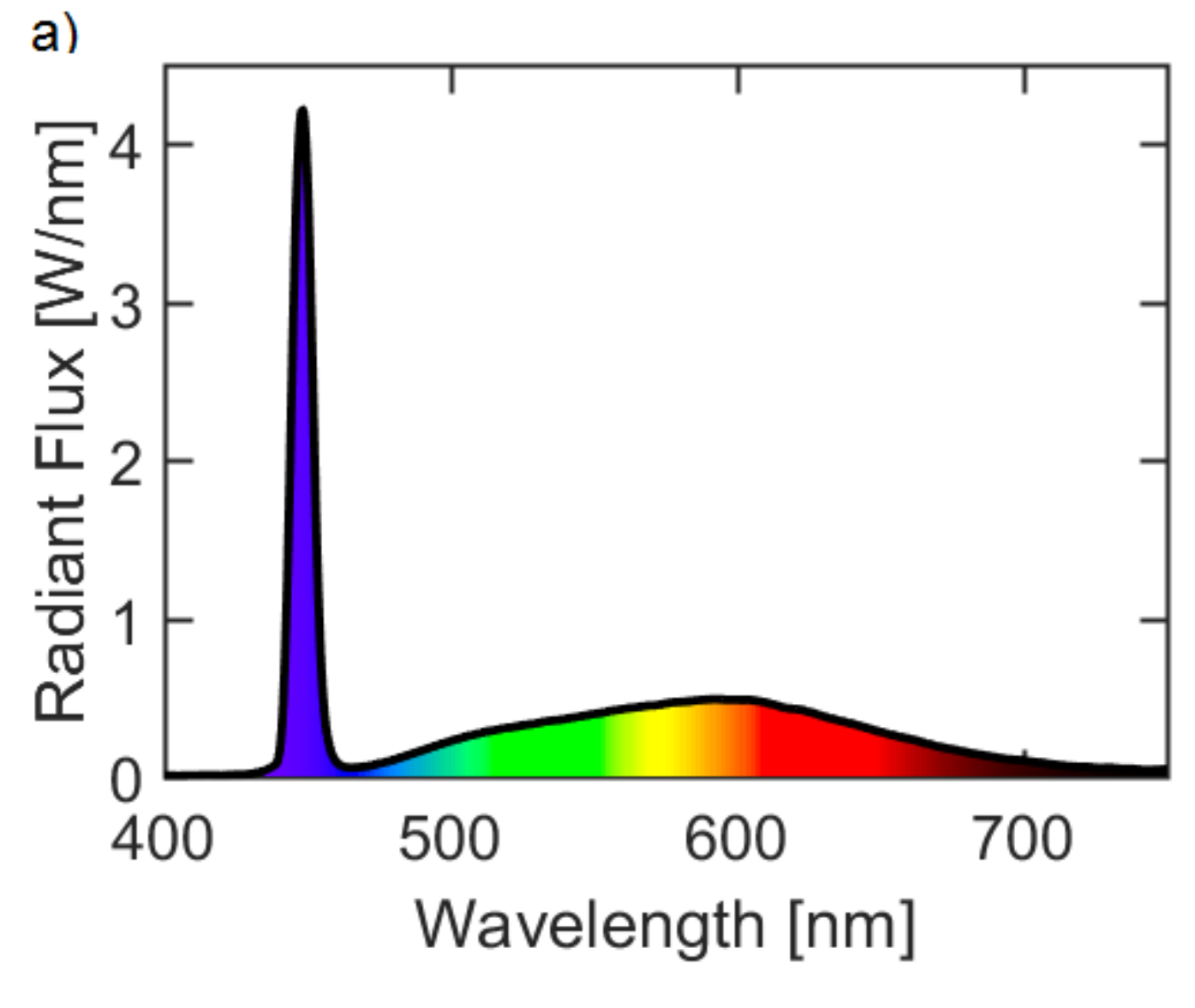

PC-LD light $\quad$ PC-LD light source at $0.3 \mathrm{~A}$ source at $0.4 \mathrm{~A}$

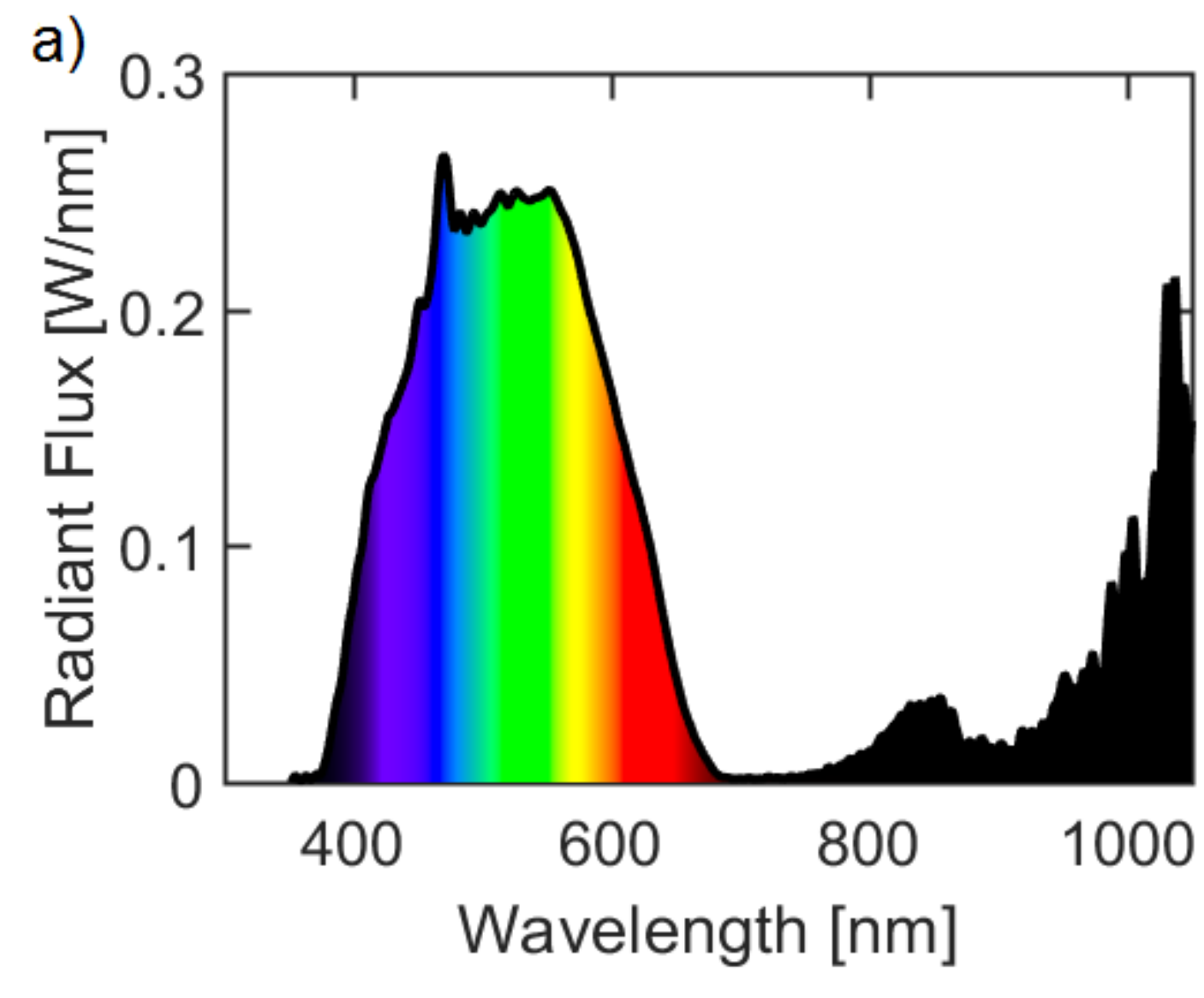

Karl Storz D Karl Storz D Light C, $40 \%$ Light C, $100 \%$ power level power level

\begin{tabular}{ccccc} 
Illuminance, $\mathrm{lx}$ & 18677 & 28592 & 6324 & 15613 \\
$\mathrm{CRI}$ & 83.3 & 85.3 & 77.7 & 75.4 \\
CCT, K & 5976 & 7972 & 6772 & 7256 \\
$\mathrm{D}_{\mathrm{uv}}$ & -0.0123 & -0.0432 & +0.0321 & +0.0366 \\
\hline
\end{tabular}
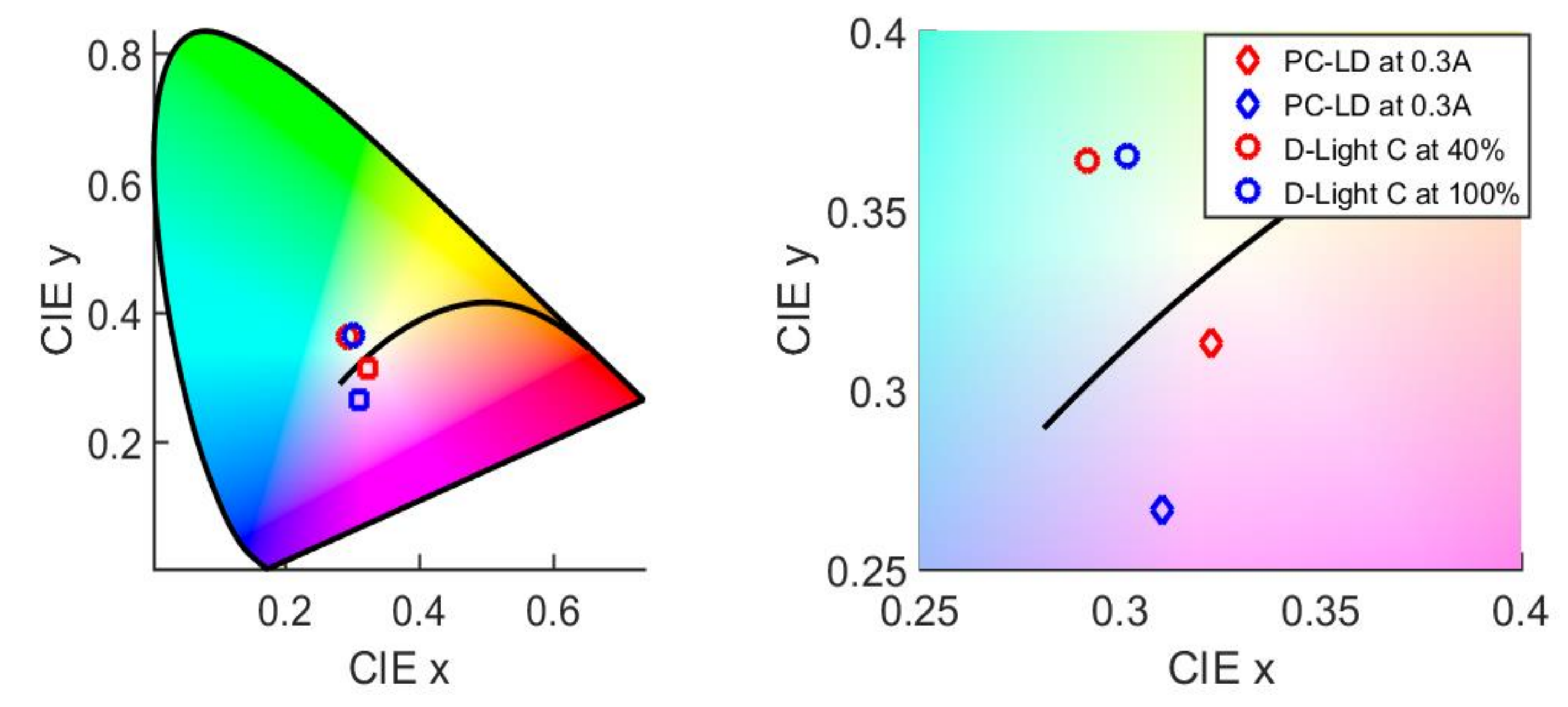

Spectral characteristics of fiber coupled generated white light from PC-LD

Power, $\mathrm{W}$

Illuminance, $1 x$

\begin{tabular}{cccc}
\hline PC-LD light & PC-LD light & PC-LD light & PC-LD light \\
source before & soupled \\
into $400 \mu \mathrm{m}$ & source coupled & source \\
into $600 \mu \mathrm{m}$ & coupled into \\
fiber coupling & fiber & fiber & $1000 \mu \mathrm{m}$ fiber \\
\hline
\end{tabular}

0.011

0.022

0.055

$\begin{array}{rrrr}4749 & 320 & 940 & 1716 \\ 8195 & 968 & 2378 & 4489 \\ 19300 & 2307 & 5272 & 10030\end{array}$

Maximal coupling efficiency of generated white light achieved - 55\% 